\title{
Teachers' Perceptions of the Use and Effectiveness of Children's Literature in the EFL Classrooms of the Primary Schools of Kuwait
}

\author{
Khaled Shuqair ${ }^{1} \&$ Abdulmuhsin Dashti ${ }^{1}$ \\ ${ }^{1}$ English Department, College of Basic Education, PAAET, Kuwait \\ Correspondence: Khaled Shuqair, English Department, College of Basic Education, PAAET, Kuwait.
}

Received: May 13, 2019 Accepted: June 13, 2019 Online Published: June 15, 2019

doi: 10.5539/elt.v12n7p87 URL: https://doi.org/10.5539/elt.v12n7p87

\begin{abstract}
The research examines the teachers' perceptions of the use and effectiveness of children's literature in their EFL classrooms in the primary public schools of the State of Kuwait. The research was conducted towards the beginning of the second semester of the academic year 2017/2018. It poses three main and interchangeable questions:

1) To what extent do teachers use children's literature in their EFL classrooms?

2) Does the school administration help towards the integration of children's literature in the EFL curriculum for the primary graders?

3) How effective is the teachers' use of children's literature in enhancing the students' proficiency in the skills of the English language?

The population of the study is the English teachers in the primary public schools in the six educational districts in Kuwait. The sample consisted of 66 English teachers selected from the 18 schools representing the six educational districts. The participants were asked to respond to a 15 -statement survey and six open-ended questions. For the first question, results showed that most of the teachers frequently use children's books in their EFL classrooms and are very much acquainted with the techniques of employing children's books in their classes and with the various genres of children's literature. For the second question, most of the participants agreed that the school administration is responsible for providing children's books. However, the results also indicated that most school administrations do not consult teachers on the books to be purchased, and, as such, these books are sometimes not suitable for use in an EFL classroom. For the third question, results showed that teachers successfully use children's books in enhancing the English skills of their EFL students, and, hence, they enrich the students' learning experience.
\end{abstract}

Keywords: children's literature, EFL, primary schools

\section{Introduction}

\subsection{Background \& Research Questions}

One of the major changes in foreign language instruction over the past decades is the shift from teaching the structural properties of the language (the grammar-translation method) to teaching expressions and meanings. This change has called for alternative instructions and methods to replace traditional methods. One of the alternatives which scholars have proposed is the use of children's literature as a source of meaningful language input and as a tool for motivating the learning of a foreign language in its context.

This research, therefore, aims at investigating the teachers' perceptions of the use and effectiveness of children's literature in teaching English in the EFL primary classes in Kuwaiti Public Schools. The research poses three main and interchangeable questions:

1) To what extent do teachers use children's literature in their EFL classrooms?

2) Does the school administration help towards the integration of children's literature in the EFL curriculum for the primary graders?

3) How effective is the teachers' use of children's literature in enhancing the students' proficiency in the skills of the English language? 
The teachers' perceptions are examined based on a 15-item survey and six open-ended questions, which address the questions posed by the research. The data of the survey was subjected to SPSS analysis, while the answers solicited from the open-ended questions were subjected to a descriptive analysis.

\subsection{Significance of the Study}

This research aims at assessing the use and effectiveness of children's literature in the EFL primary classrooms of the public schools in the State of Kuwait. Therefore, the study attempts to:

1) Investigate the extent to which the English teachers in the public schools of Kuwait use children's literature in their classrooms.

2) Determine the effectiveness of children's literature in enhancing the skills of English for an EFL learner.

3) Provide decision makers and educators at different administrative levels in the Kuwait Ministry of Education. with informed data regarding enhancing the effectiveness of the use of children's literature in primary EFL classrooms.

4) Come up with recommendations that would be beneficial to other comparable educational institutions in Kuwait, the Gulf region and the Arab World at large.

\section{Literature Review}

\subsection{The Use of Literature in an EFL Classroom}

This study is based on the view that teaching English as a foreign language is now becoming an international concern for most non-English speaking nations. However, motivating students to learn English can be challenging. For instance, one Vietnamese research has concluded that young EFL learners would get frustrated when certain vocabulary items are left unexplained by the teacher or when grammar instructions and style-points are not available (Pham, 2000). In a similar research conducted in Beirut, Lebanon, it concluded that the uninteresting materials, the absence of new learning experiences, and the unclear connection between the learners' English courses and their future professions were the major factors that demotivated students to learn English. Furthermore, the study showed that when teachers experimented with different strategies tailored to meet the needs of the learners, the students came to develop more positive learning attitudes (Bahous, 2011). As such, the challenge lies in motivating young learners to learn English, and research has shown that one of the best strategies to realize this goal is through extensive reading (Brown, 2000). Extensive reading has the virtue of motivating the young learners and enhancing their confidence and fluency to speak and write in English. However, the problem is that sometimes there is uncertainty about how to motivate students to read extensively in English. In a Japanese study by Waring and Takahashi (2000), English classes were most of the time focusing on translating English works into Japanese rather than understanding them. The authors further point out that though general translation increases understanding, it reduces English into a purely academic subject and deprives the learners of the excitement to learn the language.

For non-English speaking countries, teaching children the basic skills of the English language can be a difficult task. To achieve this objective, learning English has to begin at a young age during primary education. In Taiwan, for example, the English language was included in the primary school curricula in 2001, beginning in the third grade (Taiwan Ministry of Education, 2001). The same holds true of Korea which incorporated English as one of the main subjects in the primary school curriculum (O'Donnel, 2005). In Kuwait, English, along with Arabic, is taught in the primary stage as early as the first grade.

In the late $20^{\text {th }}$ century, scholars have already identified several difficulties that can be encountered when teaching English to EFL young learners. Research shows that the lack of interest and motivation lies at the center of the difficulties confronted by young learners in an EFL classroom. In Korea, Clark (2000) concluded that lack of motivation for learning English is a major challenge in teaching English among Korean children. Kang (2000), further, found that for the $9^{\text {th }}$-graders in Korea, English was merely an academic subject which was studied to pass the exams. This attitude among students led to problems in the reading skills. For these reasons, scholars have been questing for more effective methods of teaching the basic skills of English in an EFL classroom (Chang, 2006).

Over the years, educators have come up with teaching strategies and methods to help children learn in an EFL classroom. In Korea, for instance, a system called "CALL" or "Computer-Aided/Assisted Language Learning," was designed to help children in mastering English (O'Donnel, 2005). Another Asian research explored the use and effect of drama in enhancing the skills of English in EFL classrooms. The study concluded that drama helps motivate students and create an environment that is inducive of learning in an EFL classroom (Zyoud, 2010). 
However, among the most popular and successful teaching strategy designed is reading English from all types of literature. Brown (2000) held that extensive reading helps young learners in motivating them to read and enhance fluency in speaking and writing in English. Cary (1998) proposed the use of "contextualized storytelling" for the use of literature for EFL classrooms. Unlike the traditional means of telling stories, this strategy emphasizes the verbal performance of the readers or storytellers. Cary points out that this "multi-sensory" approach motivates learners to listen and learn more about the English language. Later, in 2005, another study capitalizes on a skills-based approach in the use of literature for EFL classrooms. The author found out that phonetic awareness is vital in helping children learn English (Anderson, 2005). Then in 2006, Hsieh concluded that a combination of physical response with storytelling is helpful in encouraging children learn English in an EFL classroom.

Literature as a school subject has been used in most English-speaking countries in the world at all school levels, but it has been recently introduced and used in the EFL classroom. In the early 1980s EFL teachers developed some interest to utilize literature in teaching English as a foreign language. Before discussing the approaches of using literature in the EFL classroom, one needs to come up with a definition of literature that is of service for the research. According to the Macmillan English dictionary, literature is defined as "stories, poems, and plays, especially those that are considered to have value as art and not just entertainment". However, a more general perspective views literature as products that manifest and display the society's different aspects. They are also products of the imagination which serve as cultural documents and yield an in-depth understanding of a society (Akyel \& Yalcin, 1993, p. 176). Other scholars view literature as the reader's interpretation of the literary text which does not possess a particular quality (Kilickaya, 2004, pp. 4-5).

Scholars have put forward a number of reasons as to why literature should be utilized in the EFL classroom. Some hold the view that literary texts are always authentic and, hence, the EFL learners are exposed to unmodified language skills that can be used outside the classroom. Secondly, literature encourages dialog because a literary text possesses several meanings which can be utilized to develop meaningful discussions and share opinions and feelings. Thirdly, literature expands an awareness of language because learners are exposed to language that is not standard, which helps in the understanding of norms associated with language use (Liaw, 2001, p. 37). Fourthly, literature holds a high status in many cultures, and, therefore, it can be motivating. Finally, literary texts are more interesting than the school textbooks, and as such they are motivating for EFL learners. However, though the use of literature has proven to be a success in teaching English in EFL classrooms, there is still an existing debate on its use and values in EFL. To mention one example, in his study Al Mullah (2006) later opposed the use of literature in EFL classrooms because, as he concludes, literary texts included difficult words that frustrated and demotivated students. Therefore, students were discouraged to learn the language. However, we believe that studies like Al Mullah's should not deter instructors from using literary texts in their EFL classrooms. The difficulty of words in texts can be easily solved through the careful selection of texts that include words suitable to the level of students.

\subsection{Literature-Based Teaching Approaches}

There are several approaches of using literature for teaching English in an EFL classroom. The teacher's use of the literary texts is highly reliant on the approach the teacher prefers for teaching. These approaches include: The cultural approach, the language approach and the personal growth approach.

The cultural approach holds that literary texts can be a source of information about a certain culture. This model is the approach that is usually utilized by instructors in EFL classrooms in the higher education institutions. This approach explores the political, historical and social backgrounds of a literary text, genres and literary movements. However, the disadvantage of this approach is that it is teacher-centered.

The language approach focuses on the learner. As EFL learners are exposed to a literary text, they are required to give great attention to the way language is used. As such, they maximize their comprehension of the meaning and raise their awareness of the English language. The instructor in an EFL classroom can use this approach to focus on vocabulary and grammar or on the stylistic analysis of the literary text. Stylistic analysis leads to a detailed study of the linguistic features in the literary text, and, therefore, learners acquire a comprehensive understanding of the literary text. The language approach works best with young learners in an EFL classroom.

The personal growth approach takes into account the step by step model and, like the language approach, it is learner-centered. This model motivates the learner to rely on their own personal experiences, opinions and feelings. It mainly focuses on creating an interaction between the reader and the text, helping the learner to recall the language easily. The learners are encouraged to view the literary text in light of their own experiences. It also utilizes the great potential and impact literature can have on people and, thus, tries to apply that in the EFL classroom setup for the young learners. 


\section{Methodology}

\subsection{Population and Sample}

The research examines the perceptions of the English teachers of the effectiveness and use of children's literature in their EFL classrooms in the primary public schools of the State of Kuwait. The research was conducted towards the beginning of the second semester of the academic year 2017/2018. The population of the study is the English teachers in the primary public schools in the six educational districts in Kuwait: Jahra, Ahmadi, Hawali, Mubaral al-Kabir, Farwaniya and Al-Asima. Currently there are about 262 primary schools in Kuwait spread across the six educational districts (Source: Transforming Education in the Gulf Region). The sample of the study was randomly selected from among these school districts: Three schools of each district totaling 18 schools. The sample consisted of about 76 English teachers selected from the 18 schools representing the six educational districts of Kuwait. The English teachers in the selected schools were asked to respond to a 15 -statement survey and six open-ended questions. The research used a number of variables against which the results were measured: The educational district (Jahra, Ahmadi, Hawali, Mubarak al-Kabir, Farwaniya and Al-Asima), age groups (22-30, 31-40, 41-50 and above 50), years of teaching experience (1-5, 6-10, 11-15, 16-20 and above 20), and nationality (Kuwaiti and non-Kuwaiti).

\subsection{Instrument \& Procedures}

Once the teachers were chosen, the researchers explained the purpose of the study and the survey to the participants. The survey and the open-ended questions were designed to obtain information about the extent to which the teachers use children's literary books in their EFL classrooms, how far the school administration helps towards the integration of children's literature in the EFL primary curriculum, and the effectiveness of children's literature in enhancing the students' proficiency in the skills of the English language.

\section{Results \& Discussion}

\subsection{The Survey}

In the analysis of the results, a scale of (disagree, don't know, agree) was used. During count of response occurrences, 10 cases were excluded as the respondents did not answer the questions. Of the 76 respondents, the total number of valid responses was 66 , from which the frequency and percentage were calculated. The results obtained from the survey with regard to the fifteen statements are shown in the table below:

Table 1. The results obtained from the survey

\begin{tabular}{|c|c|c|c|c|c|c|}
\hline \multirow[t]{2}{*}{ Statement } & \multicolumn{2}{|l|}{ Disagree } & \multicolumn{2}{|c|}{ Don’t Know } & \multicolumn{2}{|l|}{ Agree } \\
\hline & Frequency & Percent & Frequency & Percent & Frequency & Percent \\
\hline $\begin{array}{l}\text { 1) I use children's texts in my } \\
\text { classroom at least once a week }\end{array}$ & 13 & 19.7 & 1 & 1.5 & 52 & 78.8 \\
\hline $\begin{array}{l}\text { 2) I have received in service } \\
\text { training courses on how to use } \\
\text { children's literature in teaching } \\
\text { English as a foreign language }\end{array}$ & 30 & 45.5 & 3 & 4.5 & 33 & 50 \\
\hline $\begin{array}{l}\text { 3) The school library provides } \\
\text { the children's books I need in my } \\
\text { classroom }\end{array}$ & 11 & 16.7 & 4 & 6.1 & 51 & 77.3 \\
\hline $\begin{array}{l}\text { 4) I buy children's books to use } \\
\text { them in my classroom }\end{array}$ & 22 & 33.3 & 1 & 1.5 & 43 & 65.1 \\
\hline $\begin{array}{l}\text { 5) The school administration } \\
\text { consults me on the children's book } \\
\text { they order for the library }\end{array}$ & 45 & 68.2 & 7 & 10.6 & 14 & 21.3 \\
\hline $\begin{array}{l}\text { 6) I am familiar with the genres } \\
\text { of children's literature }\end{array}$ & 16 & 24.2 & 3 & 4.5 & 47 & 71.2 \\
\hline $\begin{array}{l}\text { 7) I prefer using fantasy over } \\
\text { realistic fiction in my primary } \\
\text { EFL classrooms }\end{array}$ & 12 & 18.2 & 2 & 3.0 & 52 & 78.8 \\
\hline
\end{tabular}




\begin{tabular}{|c|c|c|c|c|c|c|}
\hline $\begin{array}{l}\text { 8) I use children's literature in } \\
\text { my primary classes to clarify the } \\
\text { grammatical rules of English }\end{array}$ & 10 & 15.2 & 3 & 4.5 & 53 & 80.3 \\
\hline $\begin{array}{l}\text { 9) I use children's literature in } \\
\text { my primary classes as models of } \\
\text { good writing }\end{array}$ & 17 & 25.8 & 4 & 6.1 & 45 & 68.1 \\
\hline $\begin{array}{l}\text { 10) I use children's literature in } \\
\text { my primary classes to help my } \\
\text { EFL learners master the reading } \\
\text { skills }\end{array}$ & 4 & 6.1 & 2 & 3.0 & 60 & 91 \\
\hline $\begin{array}{l}\text { 11) I use children's literature in } \\
\text { my primary classes to enhance the } \\
\text { speaking skills of my EFL learners }\end{array}$ & 8 & 12.1 & 2 & 3.0 & 56 & 84.9 \\
\hline $\begin{array}{l}\text { 12) I use children's literature in } \\
\text { my classes to provide an } \\
\text { opportunity for discussion and } \\
\text { create dialogue }\end{array}$ & 11 & 16.7 & 3 & 4.5 & 52 & 78.8 \\
\hline $\begin{array}{l}\text { 13) I use children's literature in } \\
\text { my primary classes to teach } \\
\text { English as a foreign language in } \\
\text { its cultural/social context }\end{array}$ & 9 & 13.6 & 4 & 6.1 & 53 & 80.3 \\
\hline $\begin{array}{l}\text { 14) I believe that children's } \\
\text { books contextualize the } \\
\text { vocabulary I teach in the } \\
\text { classroom }\end{array}$ & 5 & 7.6 & 3 & 4.5 & 58 & 87.9 \\
\hline $\begin{array}{l}\text { 15) I believe that children's } \\
\text { literature helps increase the } \\
\text { vocabulary of my EFL learners }\end{array}$ & 6 & 9.1 & 0 & 0 & 60 & 90.9 \\
\hline
\end{tabular}

As the results show, most of the participants (78.8\%) expressed the opinion that they use children's texts in their EFL classrooms as opposed to $19.7 \%$ who disagreed and only $1.5 \%$ who expressed no opinion on this issue. As for whether the participants have received training courses on how to use children's literature in teaching English as a foreign language, half of the participants (50\%) agreed with the statements, while $45.5 \%$ expressed the opinion that they have not been exposed to training courses on the use of children's literary texts in an EFL classroom. $77.3 \%$ of the participants agreed with the statement that the libraries in their schools provide the books needed in the classroom, while $16.7 \%$ disagreed. $65.1 \%$ of the participants said that they also buy children's books to use them in their EFL classrooms, as opposed to $33.3 \%$ of the participants who disagreed. Only $21.3 \%$ of the participants agreed with the statement that the school administration consults them on the type of books to solicit, as opposed to the majority $(68.2 \%)$ who disagreed. As for the participants' familiarity with the genres of children's literature, the majority (71.2\%) expressed the opinion that they are familiar with the genres, as opposed to $24.2 \%$ who disagreed with the statement. Most of the participants $(78.8 \%)$ agreed with the statement that fantastic fiction is preferable to realistic fiction for primary school children, as opposed to only $18.2 \%$ of the participants who disagreed. As for the use of children's literature in enhancing the grammatical rules of English, the majority (80.3\%) were of the opinion that children's literary texts are beneficial in teaching grammar, while only $15.2 \%$ did not believe that children's literary texts can help in teaching grammar. As for the writing skill, $68.1 \%$ of the participants said that they use children's literary texts as models of good writing to be emulated by their students, while only $25.8 \%$ did not believe that children's literature is helpful in enhancing the writing proficiency of their students. The overwhelming majority of the participants $(91 \%)$ believed that children's books can help in improving the reading skills of the students, while only $6.1 \%$ of the participants disagreed. Similarly, most of the respondents $(84.9 \%)$ agreed that children's literature help in improving the speaking proficiency of their students, as opposed to $12.1 \%$ who disagreed with the statement. Most of the participants $(78.8 \%$ ) believed that children's literary texts can be helpful in establishing sustainable dialog in their classrooms, while only $16.7 \%$ of the participants opposed the statement. Similarly, $80.3 \%$ of the teachers 
believed that the use of children's books could help them in teaching English in its social/cultural context, while only $13.6 \%$ disagreed. Finally, as for the effectiveness of children's literary texts in teaching vocabulary in an EFL classroom, the majority $(87.9 \%)$ believed that children's literature is helpful in contextualizing the vocabulary; similarly, most of the teachers $(90.9 \%)$ said that children's literature is helpful in increasing the vocabulary reservoir of their EFL learners.

Statements 1, 2, 6 and 7 of the surveys target the first research question: To what extent do teachers use children's literature in their EFL classrooms? According to the results obtained, teachers in the public primary schools of Kuwait use children's literary texts in their EFL classrooms, and they are obviously familiar with the techniques of employing the literary texts for the benefit of their EFL learners. However, the results obtained for the second statement (I have received in service training courses on how to use Children's literature in teaching English as a foreign language) are not high (50\%), in comparison with those who disagreed (45\%) and those who expressed no opinion on the issue (5\%). These results might indicate that not all schools were keen on offering training courses on the use of children's literature in the EFL classroom. The results also suggest that the Ministry of Education might not have made attending these training courses mandatory for all teachers in the primary public schools. If this is the case, then that explains why a great number of teachers held that they haven't received training courses on integrating children's literary texts in their EFL curriculum. The results obtained on statements 6 and 7 also show that the participants are familiar with the various genres of children's literature $(71.2 \%$ agreed), and, as such, this knowledge would enable them to use children's literary texts effectively in their EFL classrooms. The results on statement 7 confirm their knowledge of the genres since $78.8 \%$ of the participants expressed preference for fictional fantasy over realistic fiction for their primary graders. Their opinion is in harmony with the common view held among scholars of children's literature that fantasy is the best genre to use with children because the moral values in a fantasy are presented in a concrete and comprehensible manner for children.

The second research question (Does the school administration help towards the integration of children's literature in the EFL curriculum for the primary graders?) is targeted by statements 3,4 and 5 of the surveys. Most of the participants (77.3\%) agreed the school library and administration provide the children's books needed for the school. However, the fourth statement also indicates that teachers themselves buy books for their classes out of their own pockets. The reason can probably be explained by the results obtained on statement 5 (The school administration consults me on the children's book they order for the library) where most of the teachers $(68.2 \%)$ disagreed with the statement, as opposed to only $21.3 \%$ of the participant who agreed. This most probably points out to a clash in opinion between what the school administration deems as good children's books and what the teachers do. That is to stay, the teachers seem to be dissatisfied with the selection of books the school administration makes for the library and, hence, they make up for the gap in needs by buying books out of their own pockets. The results, however, do not show if the school administration agrees with the measures the teacher take in this regard. Nor do they show whether the school administration monitor and censor the books teachers select and buy for use in their EFL classrooms.

The last eight statements target the effectiveness of children's literary texts in enhancing the skills of the English language among EFL learners. The results obtained on these statements show beyond doubt that the teachers are keenly aware of the benefits children's literary texts can bring to their EFL classrooms, whether in terms of aiding them in teaching the skills of the English language or helping them in contextualizing the English language in a genuine social and cultural context, and, hence enriching the students' learning experience. Since the natural contexts for the presentation of a children literary text is a reading program and the main activity students get involved in when exposed to a children's book is reading, results on activities related to reading were the highest. Results obtained on statement 10 (I use children's literature in my primary classes to help my EFL learners master the reading skills) scored an overwhelming majority of 91\%; likewise, results on statement 15 (I believe that children's literature helps increase the vocabulary of my EFL learners) scored the high result of $90.9 \%$.

\subsection{The Open-ended Questions}

The open-ended questions attached to the survey aimed basically to verify the results obtained from the survey. The participants didn't answer every single question; rather they were selective, and some of them chose not to answer any of the questions. However, for the most part, the participants' responses to the questions were consistent with the results of the survey as follows:

1). On a scale from 1 to 10 , rate the importance you give to the use of children's stories in teaching English (1 being the least important and 10 the most important) 
For this question, most the responses $(88.72 \%)$ rated the importance of the use of children's literature in teaching EFL above six. This goes with the results obtained from the survey, which showed that teachers are keenly aware of the benefits of employing children's stories in teaching English for their EFL learners.

2). What genre of children's literature do you prefer to teach in your EFL classes?

Most of the participants $(80.56 \%)$ who answered this question preferred the use of fantasy over realistic fiction, as opposed to only $19.44 \%$ who preferred realistic fiction. This question was also included in the survey, where most of the participants (78.8\%) preferred fantasy over any other genre of children's literature. Again, these results show that, for the most part, the participants are familiar with the genres of children's literature and with the genre of fantasy as the best genre to be used for primary graders. As stated earlier, there is a consensus among scholars and critics of children's literature that fantasy is suitable for children because this genre presents themes and values in a concrete manner, which makes them comprehensible for children. Again, the familiarity and knowledge of the participants with the genres can be attributed to a reason stated earlier: most of the participants are graduates of the Department of English in the College of Basic Education (PAAET). Among the compulsory courses offered by the Department is Children's Literature, in which students are exposed to the genres and the suitability of each genre to age groups.

3). What motivates you to use children's literature in teaching English?

The motives the participants stated and percentage for each motive are as shown in the following table:

Table 2. Participants' motives for using children's literature in their EFL classrooms

\begin{tabular}{lll}
\hline Motive & Frequency & Percentage \\
\hline Teaching Values & 7 & 7.95 \\
Enhancing the reading skill and increasing the vocabulary reservoir & 33 & 37.50 \\
$\begin{array}{l}\text { Enhancing the speaking skill and providing opportunity for discussion and dialog in } \\
\text { class }\end{array}$ & 15 & 17.05 \\
Teaching English in a genuine social/cultural context & 11 & 12.50 \\
Enriching children's imagination & 8 & 9.09 \\
Breaking the routine of the class and grabbing children's attention & 12 & 13.63 \\
Simplifying the language for children & 2 & 2.27 \\
Total & 88 & 99.99 \\
\hline
\end{tabular}

Prominent among these results and consistent with the results obtained from the survey is the response related to the use of children's literature in teaching the grammatical rules and enriching the students' vocabulary. 33 $(37.50 \%)$ of 88 responses focused on the use of children's literary books in internalizing the grammatical rules of English and increase vocabulary. This result is consistent with the results obtained from the survey about the reading skill and vocabulary which were very high. Next comes the speaking skill and establishing dialog in class. 15 out of 88 responses focused on this aspect. However, none of the responses focused on the use of children's literature in enhancing the writing skill, though according to the result obtained from the survey, $68.1 \%$ of the participants believe that children's literature can be used effectively in teaching the writing skill. We can here speculate about this disparity. The open-ended questions tell us what teachers practice when it comes to children's literature while the survey tells us more about what the participants believe how children's literature can help in teach EFL students. This means that in practice the participants focus on children's literature as primarily a reading activity more than anything else. This speculation is consistent with the fact that the responses to this question were primarily geared towards the skill of reading (including vocabulary). Another speculation we can make is that the teachers have not received training on how to employ children's literary texts in teaching the skill of writing.

1) What are the obstacles you face when you use children's literary texts in teaching EFL learners?

The obstacles the participants stated and the percentage for each obstacle are shown in the following tables: 
Table 3. Obstacles facing partipants when using children's books in their EFL classrooms

\begin{tabular}{lll}
\hline Obstacle & Frequency & Percentage \\
\hline Difficulty of the language & 18 & 27.69 \\
Lengthy curriculum and time constraint & 28 & 43.07 \\
Large class size & 14 & 21.54 \\
Unavailability of books & 5 & 7.69 \\
Total & 65 & 99.99 \\
\hline
\end{tabular}

As the figures in Table 3 show, $43.07 \%$ of the responses focused on the idea that the periods allocated for the English subject are hardly enough to cover the content of the curriculum as set by the Ministry of Education, and, therefore, they cannot afford periods for reading children's literary texts. Next comes the obstacle of language difficulty: $27.69 \%$ of the view held that the language in children's stories can sometimes be too difficult for EFL primary learners. It seems that the participants here mean that the language structure and vocabulary are sometimes above the students' level, and, hence, the participants have hard time finding children's stories that match the students' level. The third obstacle in terms of importance for the participants is the large class size. Understandably, if the class size is big, then it would be difficult for children to enjoy reading and discussing a story.

2) What are the criteria you use in selecting children's stories for your EFL primary learners?

The criteria the participants stated and the percentage for each criterion are shown in the table below:

Table 4. Criteria for selecting children's books

\begin{tabular}{lll}
\hline Criterion & Frequency & Percentage \\
\hline Age proper & 31 & 43.06 \\
Adherence to Islamic values and values of the Kuwaiti Society & 25 & 34.72 \\
Large colorful illustrations & 16 & 22.22 \\
Total & 72 & 100 \\
\hline
\end{tabular}

As the Table shows, $43.06 \%$ of the responses held that children's stories should be suitable to the children's age in terms of language and content or values. The second criterion the participants agreed on is the adherence of the values these stories teach to the values of the Islamic religion and the Kuwaiti society. The third criterion is that children's stories should contain large colorful illustrations.

3) What themes and issues you avoid when selecting a children's story for your EFL primary graders?

Table 5. Themes partipants tend to avoid when selecting children's books for their EFL classes

\begin{tabular}{lll}
\hline Themes and Issues & Frequency & Percentage \\
\hline Themes that go against Islamic Values & 30 & 40.54 \\
Social themes (violence, social and gender prejudice, sectarianism, drugs, etc.) & 30 & 40.54 \\
Political themes & 14 & 18.92 \\
Total & 74 & 100 \\
\hline
\end{tabular}

The themes the participants focused on are basically those that go against the Islamic values and the values of the society. The results here are consistent with the results obtained from Question 5, where most of the responses focused on the criterion that the children's books students should adhere to the values of Islam and of the Kuwaiti society in general.

The last part of the survey asks the participants to state any notes of significance related to the use of children's stories in teaching EFL primary learners. The responses focus on three major notes stated here in order of 


\section{importance:}

Most of the responses agreed that the school administration and library should pay more attention to the reading activity by allocating special periods for reading book as an extra-curricular activity and establishing a reading club. The second note that the participants stated is that the Ministry of Education should redesign the curriculum for English in such a way that would reduce the amount of homework and assignments and, thus, create time for teachers to use in engaging their students in reading children's books, which would improve the students' skills in English. The third note stated by the participants is that the Ministry of Education should show keener interest in children's literature and periodically offer in-service training courses on the methods used in employing children's literature in the EFL curriculum.

\subsection{Variable}

This research used a number of variables against which the results were measured: The educational district (Jahra, Ahmadi, Hawali, Mubaral al-Kabir, Farwaniya and Al-Asima), Age groups (22-30, 31-40, 41-50 and above 50), years of teaching experience (1-5, 6-10, 11-15, 16-20 and above 20), and nationality (Kuwaiti and non-Kuwaiti). As for the educational district, there were no statistically significant differences in favor of any particular district over the other. Similarly, results showed that there were no statistically significant differences for any particular age group over the other. However, with regard to the years of teaching experience, results showed that for the statement (I use children's literature in my primary classes to clarify the grammatical rules of English) there were statistically significant differences in favor of those teachers who have teaching experience extending from 1-5 years. This means that the participants with the least teaching experience show more tendency towards using children's literary texts in teaching grammar.

As for the nationality, results showed that statements 4 (I buy children's books to use in my classroom), there were statistically significant difference in favor of the Kuwaiti nationality. This means Kuwaiti teacher have the tendency to buy children's books out of their own pockets more than their non-Kuwaiti counterparts. These differences can be accounted for in different ways. First, it is possible that non-Kuwaitis cannot afford the costs of buying books from their pockets. Second, it is well known that the non-nationals in any given country tend to abide by the rule of that country. By the same token, it is possible that the non-Kuwaiti teachers would abide by the requirements as set by the school administration and would not select books not on the list set by the school administration lest they jeopardize their jobs.

Results also showed that for statements 9 (I use children's literature in my primary classes as models of good writing), 10 (I use children's literature in my primary classes to help my EFL learners master the reading skills), 11 (I use children's literature in my primary classes to enhance the speaking skills of my EFL learners) and 12 (I use children's literature in my classes to provide opportunity for discussion and create dialogue), there were statistically significant differences in favor of the Kuwaiti nationality. These differences in favor of the Kuwaiti can be accounted for. Most of the Kuwaiti teachers who teach in primary public schools are graduates of the English Department in the College of Basic Education, the Public Authority for Applied Education and Training. The major sheet of the department offers courses in children literature and in the use of literary texts in teaching the skills of the language. So, it seems that Kuwaiti teachers are more qualified than their non-Kuwaiti counterparts because they receive pre-service training on the techniques of employing children's literary texts for the enhancement of the skills among EFL learners.

\section{Conclusion}

This research aimed at investigating the teachers' perceptions of the use and effectiveness of children's literature in teaching English in the EFL primary classes in Kuwaiti Public Schools. First, results showed that most of the teachers use children's books in their EFL classrooms and are very much acquainted with the techniques of employing children's books in their classes and with the various genres of children's literature. However, the results seem also to indicate that Ministry of Education is not keen on offering in-service training on effective and updated methods of utilizing and integrating children's books in the EFL curriculum. Second, most of the participants agreed that the school library and administration are responsible for providing children's books. However, the results also indicated that most school administrations do not consult teachers on the books to be purchased, and, as such, these books are sometimes not suitable for use in an EFL classroom. Third, results showed that the teachers successfully use children's books in enhancing the English skills of their EFL students, and, hence, they enrich the students' learning experience. Fourth, most participants believed that the periods allocated for the English subject are hardly enough to cover the curriculum requirements, which makes it difficult for them to dedicate periods for reading books. Fifth, the majority of participants also agreed that the large class sizes in their schools make it difficult for their students to read and discuss stories. Finally, most 
participants held that the school administration and library should pay more attention to the reading activity by allocating special periods for reading book as an extra-curricular activity and establishing reading clubs. Along the same line, the participants believed that the Ministry of Education should redesign the curriculum for English in such a way that would reduce the amount of homework and assignments and, thus, create time for teachers to use in engaging their students in reading books, which would improve the students' skills in English.

As for the variables the research used, results showed that for the statement (I use children's literature in my primary classes to clarify the grammatical rules of English) there were statistically significant differences in favor of those teachers who have teaching experience extending from 1-5 years. This means that the participants with the least teaching experience show more tendency towards using children's literary texts in teaching grammar. Results also showed that for statement 4 (I buy children's books to use in my classroom), there were statistically significant difference in favor of the Kuwaiti nationality. This means Kuwaiti teacher have the tendency to buy children's books out of their own pockets more than their non-Kuwaiti counterparts. Results also showed that for statements 9 ( I use children's literature in my primary classes as models of good writing), 10 (I use children's literature in my primary classes to help my EFL learners master the reading skills), 11 (I use children's literature in my primary classes to enhance the speaking skills of my EFL learners) and 12 (I use children's literature in my classes to provide opportunity for discussion and create dialogue), there were statistically significant differences in favor of the Kuwaiti nationality.

\section{Recommendations}

All in all, the results of this research showed that the English teachers in the primary public schools of Kuwait utilize children books in enhancing the skills of their EFL learners and enriching their learning experience. However, there are some pitfalls that impede the use of children's literature as a source of meaningful language input and as a tool for motivating the learning of a foreign language in its context. Accordingly, by way of removing these obstacles, the researchers recommend that:

1). The school administrations get the English teachers involved in the process of selecting books for students as teachers have first-hand experience with the needs of their students.

2). The Ministry of Education periodically offer in-service training courses on the latest techniques of using children's literature in an EFL curriculum.

3). The Ministry of Education redesign the curriculum for English ns such a way that would reduce the amount of homework and assignments and, thus, create time for teachers to use in engaging their students in reading children's books, which would improve the students' skills in English.

\section{Acknowledgment}

This paper would not have been completed had it not been for the generous fund we received from the Research Sector of the Public Authority for Applied Education and Training, Kuwait. The fund was received under the Research no. BE-17-20.

\section{References}

Akyel, A., \& Yalçin, E. (1990). Literature in the EFL class: A study of goal-achievement incongruence. ELT Journal, 44(3), 174-180. https://doi.org/10.1093/elt/44.3.174

Al Mulla, K. (2007). Developing young learners' reading skills in an EFL classroom. Retrieved December 22, 2013, from http://marifa.hct.ac.ae/files/2011/07/

Anderson, S. R. (2005). Aspects of the Theory of Clitics. Oxford: Oxford University Press. https://doi.org/ 10.1093/acprof:oso/9780199279906.001.0001

Bahous, R. (2011). Motivating students in the EFL classroom: A case study of perspectives. English Language Teaching, 4(3), 33-43. https://doi.org/10.5539/elt.v4n3p33

Brown, R. (2000). Cultural continuity and ELT teacher training. ELT Journal, 54(3), 227-234. https://doi.org/10.1093/elt/54.3.227

Cary, S. (2000). Working with second language learners: Answers to teachers' top ten questions (Vol. 10). Heinemann.

Chang, A. C. S., \& Read, J. (2006). The effects of listening support on the listening performance of EFL learners. TESOL Quarterly, 40(2), 375-397. https://doi.org/10.2307/40264527

Clark, J. C. D. (2000). English society, 1660-1832: Religion, ideology and politics during the ancien regime. Cambridge: Cambridge University Press. 
Ghosn, I.-K. (2002). Four good reasons to use literature in primary ELT. ELT Journal, 56(2), 172-179. https://doi.org/10.1093/elt/56.2.172

Kang, D.-H. (2000). Motivation and Foreign Language Learning in Korean EFL Context. Retrieved January 2, 2014, from http://files.eric.ed.gov/fulltext

Kilickaya, F. (2004). Authentic materials and cultural content in EFL classrooms. The Internet TESL Journal, 10(7), 1-6.

Liaw, M. L. (2001). Exploring literary responses in an EFL classroom. Foreign Language Annals, 34(1), 35-44. https://doi.org/10.1111/j.1944-9720.2001.tb02800.x

O'Donnell, K. (2005). Japanese secondary English teachers: Negotiation of educational roles in the face of curricular reform. Language, Culture and Curriculum, 18(3), 300-315. https://doi.org/10.1080/0790831 0508668749

Pham, H. H. (2000). Traditional versus modern methods. Teacher's Edition, 2, 20-24.

Savvidou, C. (2004). An integrated approach to teaching literature in the EFL classroom. The Internet TESL Journal, 10(12).

Taiwan Ministry of Education. (2001). Retrieved April 30, 2014, from http://english.moe.gov.tw/

Van, T. T. M. (2009). The relevance of literary analysis to teaching literature in the EFL classroom. English Teaching Forum, 47(3), 2. US Department of State. Bureau of Educational and Cultural Affairs, Office of English Language Programs, Washington D.C.

Waring, R., \& Takahashi, S. (2000). The Why and How of Using Graded Readers. Tokyo: Oxford.

Zyoud, M. (2010). Using drama activities and techniques to foster teaching English as a foreign language: A theoretical perspective. Retrieved January 30, 2019, from http://www.qou.edu/english/conferences/first National Conference

\section{Copyrights}

Copyright for this article is retained by the author(s), with first publication rights granted to the journal.

This is an open-access article distributed under the terms and conditions of the Creative Commons Attribution license (http://creativecommons.org/licenses/by/4.0/). 